\title{
Determining agricultural land use scenarios in a mesoscale Bavarian watershed for modelling future water quality
}

\author{
B. B. Mehdi ${ }^{1}$, R. Ludwig ${ }^{2}$, and B. Lehner ${ }^{1}$ \\ ${ }^{1}$ McGill University, Department of Geography, 805 Sherbrooke, Montreal, QC., H3A 2K6, Canada \\ ${ }^{2}$ Department of Geography, Ludwig Maximilians University, Luisenstrasse 37, 80333 Munich, Germany
}

Correspondence to: B. B. Mehdi (bano.mehdi@mcgill.ca)

\begin{abstract}
Land use scenarios are of primordial importance when implementing a hydrological model for the purpose of determining the future quality of water in a watershed. This paper provides the background for researching potential agricultural land use changes that may take place in a mesoscale watershed, for water quality research, and describes why studying the farm scale is important. An on-going study in Bavaria examining the local drivers of change in land use is described.
\end{abstract}

\section{Introduction}

Hydrological models necessitate a number of input parameters to perform adequate simulations. Usually, one important layer of input information required for hydrological modeling is knowledge of the land cover or land use for the watershed under investigation. The land cover or land use description is specifically essential for determining the partitioning of water relevant to fluxes between the soil-vegetationatmosphere; such as interception, evapotranspiration, infiltration, or runoff.

For example, the amount and type of vegetation in the watershed (model) will dictate how much precipitation reaches the soil surface and how much is evaporated. As well, the vegetation type partly governs the three dimensional spatial distribution of water in the soil (Shuttleworth et al., 2005). The influence of land cover on hydrological processes is taken into consideration through parameters which affect these hydrological processes, i.e. through the parameters of rooting depth, canopy albedo or leaf area index (Alcamo et al., 2003).
Land use information is particularly critical for modelling the quality of water (Stonestrom et al., 2009), as such, land use considerations are prominent in water quality models. For example, the hydrological model SWAT (Arnold et al., 1998) contains numerous parameters that define the agricultural management components: information is required for tillage, irrigation, fertilization, grazing, and conservation management practices. Additionally, the model has separate sub-models related to pesticides (GLEAMS) and crop growth (EPIC).

When applying water quality models to primarily rural watersheds, agricultural land use should be represented in sufficient detail because this governs processes (i.e. surface runoff) which significantly influence sediment and nutrient transport. For example, arable land is more prone to generate surface runoff than pasture or forest areas (Eckhardt et al., 2003), and certain land uses (i.e. the area of maize cropland) have been found to be particularly strongly correlated to inorganic pollutant amounts in water bodies (Donner, 2003). Therefore, accounting for agricultural land use is critical when assessing the quality of water in rural areas.

Several watershed studies, in various parts of the world, have examined the impacts of future changes on water quality (e.g. Ficklin et al., 2009; van Vliet and Zwolsman, 2008; Wilby et al., 2006). However, the magnitude of the impacts of future changes on agricultural landscapes, and the consequent impacts of climate change on the quality of water are largely unknown (IPCC, 2007). Most studies examining the impacts of climate change on water quality have assumed a static landscape. Our study undertakes an examination of the surface water quality in a future temporal frame while considering the possibility of an evolving landscape in the watershed, so that the relevant land cover and land use parameters can be adequately represented in the hydrological model. To do this, future land use scenarios must be determined. 
This paper will describe the concepts of agricultural land use modelling, with a particular focus on the farm level scale of modelling, and the drivers of cropping system change. It will also describe an on-going study in Bavaria examining the drivers of land use change at the farm level.

\section{Concepts for modelling agricultural land use change}

Land use has been loosely defined by Lambin and Geist (2006) as "the purposes for which humans exploit the land cover". A term frequently used to denote agricultural land use systems is "cropping systems". In agricultural sciences, a cropping system is defined by FAO (1996) as: "A system (or land use unit), comprising soil, crop, weeds, pathogen and insect sub-systems, that transforms solar energy, water, nutrients, labour and other inputs into food, feed, fuel or fibre".

From an agricultural view point, land use is perhaps of greater interest than land cover, because land use includes a breakdown of the crops in the landscape, and sometimes also provides the different tillage and residue management practices, which land cover data cannot capture. For example, the CORINE land cover database (EEA, 2010) has four categories related to agricultural land cover (non-irrigated arable land; pastures; complex cultivation patterns; land principally occupied by agriculture, with significant areas of natural vegetation). A land use based classification, however, subdivides agricultural areas into specific types of cropland (e.g. GLOWA DANUBIA Project (Mauser et al., 2004)), specifying the dominant crop or vegetation type in each pixel.

To determine future agricultural land uses or cropping systems in a watershed, land use models can be interesting tools to apply since they can provide a range of potential future scenarios. Land use models which represent the spatial distribution of land type (e.g. CLUE, Geomod, Land Use Scanner, SAMBA, SLEUTH, ProLand) are particularly useful for applying to water quality modeling research because they provide the spatial proximity of crops to surface water bodies.

Land use models specifically developed to model agricultural land use changes, for example the CLUE model (Veldkamp and Fresco, 1996), require in depth knowledge as well as data of the agricultural sector in the study area, and tend to be applied to the regional, or finer spatial scales. To determine future agricultural land use changes that may take place, land use models build scenarios based on a range of plausible vectors of change, known as driving factors.

In the following sections, two main concepts will be elaborated on: the scales of land use modelling, particularly the scale relevant for agricultural land use modelling; and the drivers of change relevant to agricultural land use.

\subsection{Scale of land use modelling}

Some of the spatial scales used for studying land use change include: global (world); continental (continents); national (country level, defined by national boundaries); regional (major watershed, or defined region, e.g. province or state); local (sub-watershed or municipality); or farm (individual field level).

The spatial scale used by the researcher for land use scenario modeling will vary depending on the level of detail necessary in the study. Usually coarse spatial scales (greater than $1 \mathrm{~km}$ by $1 \mathrm{~km}$ ) are useful to reveal the general trends and relations between land use and its determining factors. Factors that influence land cover over a considerable distance also use the coarse scale. The finer scale is used for understanding processes pertaining to a specific region, or understanding a certain type of behaviour, such as decision-making or planning. For regional studies, the scale of $1 \mathrm{~km}$ by $1 \mathrm{~km}$ or less can be used, whereas the household or farm system scale uses resolutions of less than $250 \mathrm{~m}$ by $250 \mathrm{~m}$ (FAO, 1996; Verburg et al., 2008).

A change in agricultural land use involves altering the location, nature, or quantity of agricultural crop or livestock production units per area (Smit and Skinner, 2002). To ascertain drivers of change at the farm level, several levels need to be considered (Bürgi et al., 2004). Larger scale drivers (e.g. markets or policies) tend to influence decisions made at the farm level. Often there is an iterative interaction between these two scales, as is evident from one of the more influential agricultural policies implemented in Europe, the Common Agricultural Policy (Lobley and Butler, 2010).

A farm system is defined as (Fresco, 1990): "A decision making unit, comprising the farm household, cropping and livestock systems that produces crop and animal products for consumption and/or sale". Most land use models do not tend to examine the farm level (Overmars and Verburg, 2005; Houet et al., 2010), perhaps due to the required integration of social and physical sciences (Verburg et al., 2004) which is not undemanding, or because it is difficult to predict the evolution of crop land use at a watershed scale due to the complex relationships between producers and their management of land resources (Lambin et al., 2000), or because the spatial-temporal evolution of land-use is highly site-specific and thus difficult to draw out generalizations that can be plugged into a larger scale model.

Examining the farm scale calls for detailed studies of the individual watershed, and often due to resource constraints this is not undertaken. As a result, the information necessary at the farm level for input into non-economic type land use models has tended to be assumed based on knowledge of the area, rather than collected from farmers (Verburg et al., 2002), and usually the assumptions for land use change are based on economic incentives for the producer (O'Neal et al., 2005). There is a general lack of research undertaken in developed countries that examine land use drivers at the 


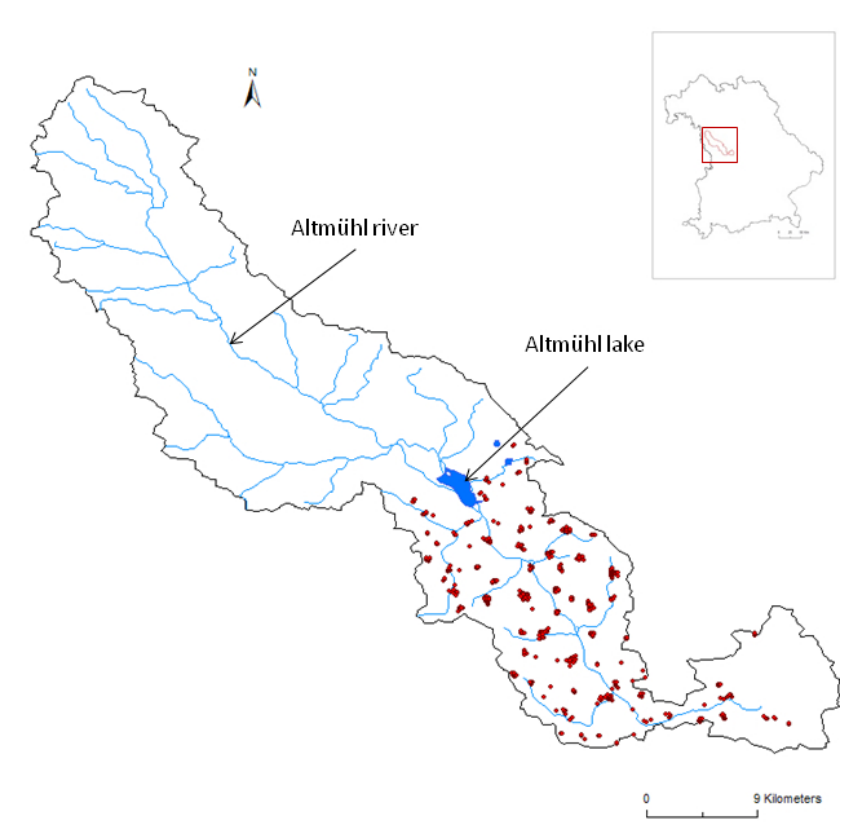

Fig. 1. Location of farms in the study area (upper Altmühl watershed) where a questionnaire was sent (each dot represents a farm address). Inset shows location of the watershed in the State of Bavaria, Germany. (Map source information: Bayerisches Vermessungsverwaltung, 2010).

farm scale. Yet, such studies are important, to reveal if drivers other than financial drivers are responsible for land use decisions in the watershed; such as tradition, local culture, family know-how and technology. And to what extent these are important drivers of future land use change.

\subsection{Driving factors of land use change}

Drivers of land use change can be distinguished into two broad categories; direct and underlying drivers (Lambin and Geist, 2006). Direct drivers are immediate actions or activities which cause a change. These causes are usually - but not always - local in scale (i.e. producer or household level) and involve a physical action limited to specific agricultural activities. Underlying drivers are more diffuse in nature and usually operate at a larger scale, such as the regional or national level. They influence the direct drivers through incentives, such as economic, technological, or demographic (Lambin and Geist, 2006). Both direct and underlying factors interact with one another and have feedbacks with each other.

The literature contains few direct or indirect driving factors influential at shaping land use in developed regions at the local (farm) scale. By examining the literature relevant for Europe, the following drivers influencing agricultural land use were found: the type of producer (based on age, education, innovation and farm characteristics) (Bakker and van Doorn, 2009); the economic return available for the land

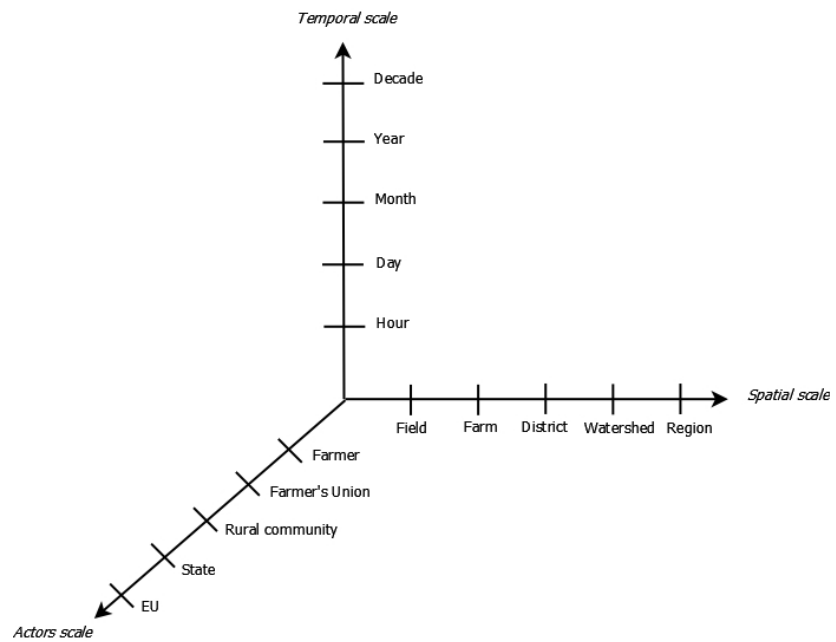

Fig. 2. Temporal, spatial and actor scales, showing both the extent and resolution studied for determining future scenarios of land use change (adapted from Bürgi et al., 2004).

(Dockerty et al., 2006); social characteristics of the farmers (Veldkamp and Lambin, 2001); geophysical features, accessibility to markets, demand for food, available technology, and government subsidies (Bürgi et al., 2004; Schröter et al., 2005; Busch, 2006).

The challenge of applying drivers of land use change is that they are site-specific, and scale-dependant. Therefore, they are not necessarily transposable to watersheds other than those for which they were determined (Bürgi et al., 2004), nor at a different scale (Overmars and Verburg, 2006), unless very similar conditions prevail in the watersheds, and the same spatial resolution is examined. As such, it may be necessary to carry out independent studies determining the drivers of land use change for each watershed studied. This can be an onerous and resource intensive undertaking, as much quantitative and qualitative data is required (Overmars and Verburg, 2005; Verburg, 2002).

\section{Determining land use change at the local scale}

In an on-going study in southern Bavaria, future land use scenarios for the upper Altmühl watershed, to the gauge at Treuchtlingen, $\left(980 \mathrm{~km}^{2}\right)$, are being developed to the year 2040 (Fig. 1). A spatial resolution (pixel) of $50 \mathrm{~m}$ by $50 \mathrm{~m}$ is used. This unit coincides with the unit of decision making (the farm), since the average farm size in the watershed is 10 to 20 ha (BLSD, 2010). Three spatial levels are being studied; the farm level (individual and local), the regional level (rural district and state) and the national level (country or continental). A particular emphasis is placed on the farm (local) level which is relevant to decision making for land use change in the mesoscale watershed. Land use change studies have scale extents and resolution. Figure 2 depicts the various 
spatial, temporal and actor scales used for determining future land use scenarios in the study.

In order to describe land use change at the farm scale, current driving factors of change were determined based on local factors influencing the decisions made by producers in the watershed. First, a detailed, in depth study of the environmental, socio-economical, political, and cultural aspects was conducted in the watershed. This involved several site visits, attending local conferences on water quality, and reading relevant literature. The information gathered was helpful for identifying casual relationships of land use, which are essential to land use modelling (Bürgi et al., 2004). Furthermore, a number of additional, detailed, steps were undertaken, which included liaising with a local university; meetings and discussions with relevant agricultural and water management stakeholders (ministries and local authorities); querying farmers; and collecting or requesting the relevant digital data pertaining to the watershed (e.g. DEM, soil, topography, precipitation, historic land use/land cover) from government sources mostly.

For the purpose of investigating potential future direct drivers of land use change at the farm level, the administration of a postal questionnaire in a subset of the watershed was undertaken. The questionnaire was compiled with input from partner universities, the regional administrative office for Food, Agriculture and Forests, as well as the Farmers' Union. The questionnaire consisted of 23 questions (time to complete was less than $30 \mathrm{~min}$ ) and was sent to all producers located below the Altmühl lake; a total of 666 farms (Fig. 1). The questionnaire was voluntary, and could be filled out anonymously. The responses (received responses from $8 \%$ of the farmers questioned) were used to ascertain decision making factors that govern current crop land use on the farm, as well as to determine drivers which apply to changes in growing crops in the future. To determine larger scale drivers, regional and national drivers of land use change were established through the literature and through consultation with experts (Ministries and agricultural stakeholder groups). The information from these drivers will be incorporated into a land use model.

The CLUE-S model (Conversion of Land Use and its Effects-Small scale; Verburg et al., 2002) is an example of a model that is able to dynamically forecast agricultural land use change at the local level, and integrate the various spatial levels and their driving factors related to land use change. Based on empirically quantifiable relationships between land use and driving factors, CLUE-S is being applied to the watershed to simulate several scenarios of the spatial distribution of land use to 2040 in the Altmühl watershed. The information gleaned from the questionnaire responses will be used to determine drivers and to guide the development of future scenarios regarding changes that may occur.

\section{Description of CLUE-S land use model}

The CLUE-S model simulates the spatial distribution of land use patterns in the near future based on present and historical land use, and on competition between land use in space and time. The model is based on an analysis of the spatial structure of the land rather than on the economy, or on the individual behaviour (Verburg et al., 2004).

The model uses regression equations to determine the location suitability of a crop. Driving factors that were significant in the Altmühl watershed are provided in Table 1. The drivers of land use change differ according to the crop type. Table 1 provides an impression of the breadth of diverse (qualitative and quantitative) factors found to be statistically significant from an even larger suite of possible factors, at the regional scale.

Since there is no prior knowledge of why certain land uses occur in the study watershed, a stepwise logistic regression analysis was used to explore a suite of biophysical variables determining current land use. A stepwise forward binary logistical regression was implemented for each land type of interest, using a significant entry value of 0.01 , and a significant removal value of 0.02 .

The logistical regressions will also be established at the national and at the local scale to determine relevant drivers of land use change at three different scales in total.

The CLUE-S model allows the user to specify demands for each crop type for every simulation year. Through this demand table, the model accounts for changing conditions of land use requirements as well as shifting demands for agricultural products. The competition between crop land uses can be defined, and the overall flexibility of a land use to transform can be defined. The model is particularly interesting for examining agricultural scenarios at the farm scale because it is able to integrate drivers of land use change at different spatial levels (e.g. the farm level, the regional level, and the national level) through the logistical regression equations (for detailed information see Verburg et al., 2004).

Factors related to individual behaviour are taken into consideration when the aggregate amount of land area for each crop type is determined each simulation year, which is how the information from the questionnaires is taking into consideration.

The outputs of the CLUE model are ASCII files that can be imported into a Geographich Information Systems (GIS) to view maps of spatially allotted land use types. These correspond to the land use quantities (demand table) defined by the user each year, and depicts their spatially allocation according to the location suitability, the competition between crops, the flexibility of each land use to change, and other defining factors, such as neighbourhood functions, etc..

The future land use scenarios will be inserted into a hydrological model to determine the impacts on surface water quality. Of particular interest is the expansion of crop acreage related to biofuels, such as maize, as these may lead 
Table 1. Significant local biophysical factors for determining the location of crop types in the upper Altmühl watershed (based on data from 2008-2010).

\begin{tabular}{|c|c|c|c|c|c|c|c|c|c|c|c|}
\hline Land use & $\begin{array}{l}\text { Location } \\
\text { factor } 1\end{array}$ & $\begin{array}{l}\text { Location } \\
\text { factor } 2\end{array}$ & $\begin{array}{l}\text { Location } \\
\text { factor } 3\end{array}$ & $\begin{array}{l}\text { Location } \\
\text { factor } 4\end{array}$ & $\begin{array}{l}\text { Location } \\
\text { factor } 5\end{array}$ & $\begin{array}{l}\text { Location } \\
\text { factor } 6\end{array}$ & $\begin{array}{l}\text { Location } \\
\text { factor } 7\end{array}$ & $\begin{array}{l}\text { Location } \\
\text { factor } 8\end{array}$ & $\begin{array}{l}\text { Location } \\
\text { factor } 9\end{array}$ & ROC $^{1}$ & $\begin{array}{l}\text { Sample } \\
\text { size }^{2}\end{array}$ \\
\hline Grain corn & Density of beef cows & Density of pigs & Density of cows & Loam & Loamy sand & Heavy loam & Heavy loamy sand & Slope & & 0.76 & $60 \%$ \\
\hline Silage corn & Density of beef cows & Loam & Loamy sand & Heavy loam & Heavy loamy sand & Slope & Biogas plants $(\mathrm{kW})$ & & & 0.70 & $30 \%$ \\
\hline Cereal & Density of pigs & Density of chicken & Loam & Loamy sand & Heavy loam & Distance to main river & Slope & Distance to urban centre & Biogas plants $(\mathrm{kW})$ & 0.63 & $30 \%$ \\
\hline $\begin{array}{l}\text { Winter } \\
\text { wheat }\end{array}$ & Density of pigs & Density of cows & Density of chicken & Density of beef cows & Loam & Loamy sand & Heavy loam & Distance to main river & & 0.67 & $30 \%$ \\
\hline Miscanthus & Distance to urban centre & & & & & & & & & 0.74 & $100 \%$ \\
\hline Alfalfa & Density of cows & Density of pigs & Loam & Heavy loam & Heavy loamy sand & Biogas plants (kW) & & & & 0.66 & $80 \%$ \\
\hline Soyabean & Density of cows & Heavy loamy sand & Slope & Biogas plants $(\mathrm{kW})$ & & & & & & 0.65 & $80 \%$ \\
\hline Oilseed & Loam & Heavy loam & Loamy sand & Distance to urban centre & Population density & Slope & & & & 0.66 & $60 \%$ \\
\hline Vegetable & Population density $/ \mathrm{km}$ & Distance main river & Loam & & & & & & & 0.72 & $80 \%$ \\
\hline Sugarbeet & Population density & Loam & Distance to main river & Biogas plants $(\mathrm{kW})$ & & & & & & 0.70 & $80 \%$ \\
\hline Berries & Population density & & & & & & & & & 0.83 & $100 \%$ \\
\hline Pasture & Distance to main river & Clay & Loam & Loamy sand & Density of horses & Distance to forest & Density of cows & & & 0.81 & $30 \%$ \\
\hline Rangeland & Clay & Erosion prone areas & Distance to urban centre & Loamy sand & Density of horses & & & & & 0.64 & $80 \%$ \\
\hline Orchard & Distance to urban centre & Distance to main river & & & & & & & & 0.73 & $100 \%$ \\
\hline Forest & Distance to urban centre & Slope & Distance to road & Distance to main river & Elevation & Population density & & & & 0.78 & $30 \%$ \\
\hline Urban & Population density & Distance to roads & Distance to main river & Distance to forest & Slope & & & & & 0.72 & $50 \%$ \\
\hline
\end{tabular}

1 ROC = relative operating characteristic (Pontius and Schneider, 2001)

2 Sample size is based on the total area of each crop type in the watershed.

to water quality challenges, since they require higher inputs. The yearly land use scenarios will provide information on the quantities of different crops in the watershed, as well as their spatial distribution. From this, we can infer the quantities of fertilizer applied, as well as farm management practices. Finally, relevant crop parameters such as rooting depth, transpiration and water uptake will also be able to be deduced. All of this is information that is important for modelling hydrological surface water quality for the future.

\section{Summary}

Land cover and land use are important because they provide parameters relevant to water quality modelling. Future land use scenarios can be developed through the application of land use models, which necessitate determining the driving factors of land use change. The determining factors for land use should be determined at several spatial levels.

Agricultural land use change is highly site specific and therefore the local scale of study can be very helpful to link specific land uses to impacts on water quality. The general lack of land use change information at the farm level in the literature requires a large number of assumptions for modelling purposes, and contributes to uncertainties in the scenario development exercise. By applying the CLUE-S model in combination with a household questionnaire we hope to provide insight into drivers of land use change at the farm level.
Acknowledgements. Funding for the research outlined was received from the National Sciences and Engineering Research Council of Canada, and from the Québec ministère du Développement économique, Innovation et Exportation. The authors would like to thank the following for their valuable cooperation: Bayerischer Bauernverband, Amt für Ernährung, Landwirtschaft und Forsten Ansbach, Wasserwirtschaftsamt Ansbach, and the Ludwig Maximilians Universität.

Edited by: R. Ludwig, K. Schulz, and M. Disse

Reviewed by: two anonymous referees

\section{References}

Alcamo, J., Döll, P., Henrichs, T., Kasper, F., Lehner, B., Rösch T., and Siebert, S.: Development and testing of the WaterGAP 2 global model of water use and availability, Hydrolog. Sci. J., 48, 317-338, 2003.

Arnold, J. G., Srinivasan, R., Muttiah, R. S., and Williams, J. R.: Large area hydrologic modeling and assessment part I: Model development, J. Am. Water Resour. As., 34, 73-89, 1998.

Bakker, M. M. and van Doorn, A. M.: Farmer-specific relationships between land use change and landscape factors: Introducing agents in empirical land use modelling, Land Use Policy, 26, 809-817, 2009.

BLSD (Bayerisches Landesamt für Statistik und Datenverarbeitung): Landwirtschaftliche Betriebe in Bayern 2005, www. statistik.bayern.de/veroeffentlichungen/?themenbereich $=3400$, 2010.

Bürgi, M., Hersperger, A. M., and Schneeberger, N.: Driving forces of landscape change - current and new directions, Landscape Ecol., 19, 857-868, 2004.

Busch, G.: Future European agricultural landscapes - What can we learn from existing quantitative land use scenario studies?, Agric. Ecosyst. Environ., 114, 121-140, 2006.

Dockerty, T., Lovett, A., Appleton, K., Bone, A., and Sunnenberg, G.: Developing scenarios and visualisations to illustrate potential 
policy and climatic influences on future agricultural landscapes, Agric. Ecosyst. Environ., 114, 103-120, 2006.

Donner, S.: The impact of cropland cover on river nutrient levels in the Mississippi River Basin, Global Ecol. Biogeogr., 12, 341355, 2003.

Eckhardt, K., Breuer, L., and Frede, H. G.: Parameter uncertainty and the significance of simulated land use change effects, J. Hydrol., 273, 164-176, 2003.

EEA (European Environmental Agency): CORINE Land Cover 2000, www.eea.europa.eu/publications/COR0-landcover, 2010.

FAO Guidelines: Agro-ecological zoning. FAO Soils Bulletin 73, FAO, Rome, 1996.

Ficklin, D. L., Luo, Y., Luedeling, E., and Zhang, M.: Climate change sensitivity assessment of a highly agricultural watershed using SWAT, J. Hydrol., 374, 16-29, 2009.

Fresco, L. O.: Using Land Evaluation and Farming Systems Methods for Planning Sustainable Land Use-An Example from Costa Rica (Chapter 16), in: World Soil Resources Report 68: Land use planning applications: Proceedings of the FAO Expert Consultation 1990, Rome, Italy, 1990.

Houet, T., Loveland, T. R., Hubert-Moy, L., Gaucherel, C., Napton, D., Barnes, C. A., and Sayler, K.: Exploring subtle land use and land cover changes: a framework for future landscape studies, Landscape Ecol., 25, 249-266, 2010.

IPCC (Intergovernmental Panel on Climate Change): Freshwater Resources and their Management (Chapter 3), in: Climate Change 2007: Impacts, Adaptation and Vulnerability. Contribution of Working Group II to the Fourth Assessment Report of the Intergovernmental Panel on Climate Change, Cambridge, UK, Cambridge University Press, 2007.

Lambin, E. F. and Geist, H. (Eds.): Land use and land cover change: Local processes and global impacts, Global Change - The IGBP Series, New York, Springer, 2006.

Lambin, E. F., Rounsevell, M. D. A., and Geist, H.J.: Are agricultural land-use models able to predict changes in land-use intensity?, Agric. Ecosyst. Environ., 82, 321-331, 2000.

Lobley, M. and Butler, A.: The impact of CAP reform on farmers' plans for the future: Some evidence from South West England, Food Policy, 35, 341-348, 2010.

Mauser, W., Ludwig, R., Löw, A., and Willems, W.: A multiscale validation approach for the simulation of sustainable water resources managment in the Upper Danube watershed using ENVISAT data in the frame of GLOWA-Danube, Hydrol. Wasserbewirts., 48, 225-235, 2004

O’Neal, M. R., Nearing, M. A., Vining, R. C., Southworth, J., and Pfeifer, R. A.: Climate change impacts on soil erosion in Midwest United States with changes in crop management, Catena, 61, 165-184, 2005.

Overmars, K. P. and Verburg, P. H.: Analysis of land use drivers at the watershed and household level: Linking two paradigms at the Philippine forest fringe, Int. J. Geogr. Inf. Sci., 19, 125-152, 2005.
Overmars, K. P. and Verburg, P. H.: Multilevel modelling of land use from field to village level in the Philippines, Agr. Syst., 89, 435-456, 2006.

Pontius Jr., R. G. and Schneider, L. C.: Land-cover change model validation by an ROC method for the Ipswich watershed, Massachusetts, USA. Agric. Ecosyst. Environ., 85, 239-248, 2001.

Schröter, D., Cramer, W., Leemans, R., Prentice, I. C., Araujo, M. B., Arnell, N. W., Bondeau, A., Bugmann, H., Carter, T. R., Gracia, C. A., De La Vega-Leinert, A. C., Erhard, M., Ewert, F., Glendining, M., House, J. I., Kankaanpää, S., Klein, R. J. T., Lavorel, S., Lindner, M., Metzger, M. J., Meyer, J., Mitchell, T. D., Reginster, I., Rounsevell, M., Sabaté, S., Sitch, S., Smith, B., Smith, J., Smith, P., Sykes, M. T., Thonicke, K., Thuiller, W., Tuck, G., Zaehle, S., and Zierl, B.: Ecology: Ecosystem service supply and vulnerability to global change in Europe, Science, 310, 1333-1337, 2005.

Shuttleworth, J., Carrera, J., and Kabat, P.: Cycles, Feedbacks, and Main Issues (Chapter 1), in: Coupled Models for the Hydrological Cycle, edited by: Bronstert, A., Carrera, J., Kabat, P., and Lütkemeier, S., Berlin, Germany, Springer, 2-73, 2005.

Smit, B. and Skinner, M. W.: Adaptation options in agriculture to climate change: A typology, Mitigation and Adaptation Strategies for Global Change, 7, 85-114, 2002.

Stonestrom, D. A., Scanlon, B. R., and Zhang, L: Introduction to special section on Impacts of Land Use Change on Water Resources, Water Resour. Res., 45, W00A00, doi:10.1029/2009WR007937, 2009.

Veldkamp, A. and Fresco, L. O.: CLUE: A conceptual model to study the conversion of land use and its effects, Ecol. Model., 85, 253-270, 1996.

Veldkamp, A. and Lambin E. F.: Predicting land-use change, Agric. Ecosyst. Environ., 85, 1-6, 2001.

Verburg, P. H., Soepboer, W., Veldkamp, A., Limpiada, R., Espaldon, V., and Mastura, S. S. A.: Modeling the spatial dynamics of regional land use: The CLUE-S model, J. Environ. Manage., 30, 391-405, 2002.

Verburg, P. H., Schot, P. P., Dijst, M. J., and Veldkamp, A.: Land use change modelling: Current practice and research priorities, GeoJournal, 61, 309-324, 2004.

Verburg, P. H., Eickout, B., and Meijl, H.: A multi-scale, multimodel approach for analyzing the future dynamics of European land use, Ann. Reg. Sci., 42, 57-77, 2008.

Van Vliet, M. T. H. and Zwolsman, J. J. G.: Impact of summer droughts on the water quality of the Meuse river, J. Hydrol., 353, $1-17,2008$.

Wilby, R. L., Whitehead, P. G., Wade, A. J., Butterfield, D., Davis, R. J., and Watts, G.: Integrated modeling of climate change impacts on water resources and quality in a lowland catchment: River Kennet, UK, J. Hydrol., 330, 204-220, 2006. 